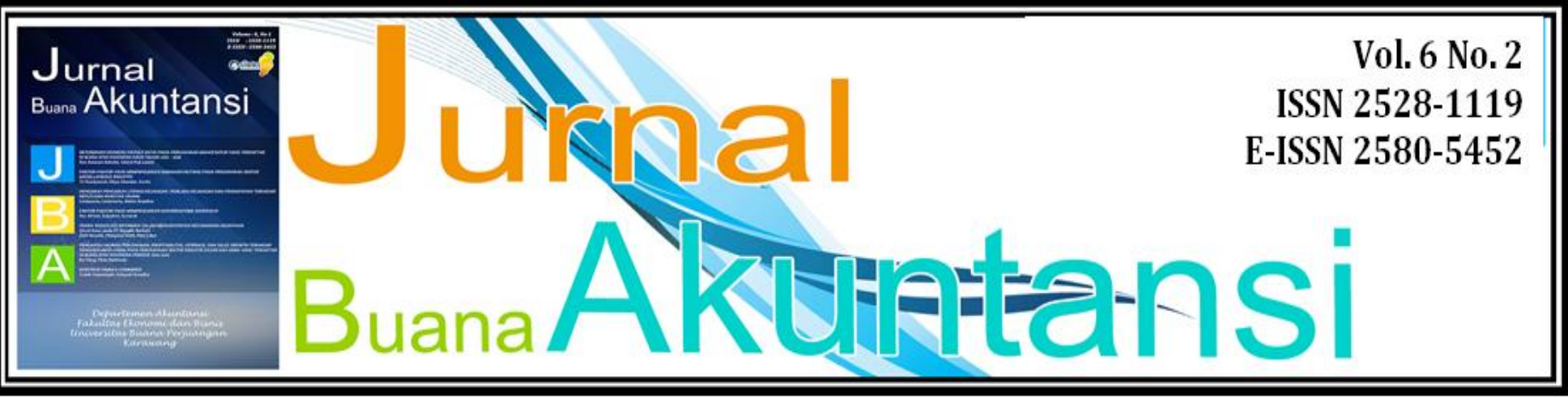

\title{
Analisis Financial Distress pada Perusahaan Sub Sektor Transportasi di Bursa Efek Indonesia
}

\author{
${ }^{1}$ Ade Elza Surachman \\ ${ }^{1}$ STIE Wibawa Karta Raharja, Purwakarta, Indonesia \\ ${ }^{1}$ e-mail: adeelzasurachman@gmail.com
}

\begin{abstract}
Abstrak
Penelitian ini memiliki tujuan untuk melakukan prediksi kesulitan keuangan pada Perusahaan Sub Sektor Transprotasi di Bursa Efek Indonesia tahun 2019-2020. Manfaat dari penelitian ini adalah memberikan peringatan dini adanya kebangkrutan di masa depan. Metode penelitian menggunakan analisis deskriptif dengan teknik purposive sampling berjumlah 26 perusahaan. Hasil penelitian menunjukkan bahwa perusahaan Sub Sektor Transportasi di Bursa Efek Indonesia pada tahun 2019 terdapat 10 perusahaan berada pada zona berbahaya, 5 perusahaan pada zona abu-abu, dan 10 perusahaan berada pada zona aman. Sedangkan, tahun 2020 terdapat 12 perusahaan berada pada zona berbahaya, 6 perusahaan pada zona abu-abu, dan 8 perusahaan berada pada zona aman.

Kata Kunci : Financial Distress, Altman Z Score, Sektor Transportasi Bursa Efek Indonesia.
\end{abstract}

\section{Pendahuluan}

Sejak pandemi covid-19 melanda Indonesia di tahun 2020 sampai dengan 2021 telah mengakibatkan penurunan laba bagi perusahaan. Pembatasan sosial berskala besar membuat perusahaan berhenti produksi/jasa untuk sementara waktu sampai dengan batas waktu yang ditentukan oleh Pemerintah. Disamping itu, perusahaan jasa seperti bidang transportasi turut merasakan dampak yang signifikan dari aturan tersebut. Sebagaimana yang tertuang dalam Peraturan Pemerintah No. 21 Pasal 4 Tahun 2020 tentang PSBB dalam rangka penanganan Covid-19 meliputi pembatasan kegiatan di tempat atau fasilitas umum. Hal ini menyebabkan penurunan pendapatan yang berdampak langsung pada perolehan laba.

Perusahaan pada sub sektor transportasi di Bursa Efek Indonesia mengalami penurunan laba dari tahun 2019-2020 sebagai berikut 
Tabel 1

Perolehan Laba/Rugi dan Pertumbuhan Laba Perusahaan Transportasi yang Terdaftar Di Bursa Efek Indonesia Tahun 2019-2020

\begin{tabular}{|c|c|c|c|c|c|c|}
\hline \multirow{2}{*}{ No } & \multirow{2}{*}{ Kode/Nama Perusahaan } & \multicolumn{3}{|c|}{ Laba/Rugi (Jutaan Rp) } & \multicolumn{2}{|c|}{$\begin{array}{l}\text { Pertumbuhan } \\
\text { Laba }\end{array}$} \\
\hline & & 2018 & 2019 & 2020 & 2019 & 2020 \\
\hline 1 & PT. Adi Sarana Arr & 142.242 & 91.615 & 63.896 & $-36 \%$ & $-30 \%$ \\
\hline 2 & PT. Blue Bird Tbk & 460.273 & 315.622 & $(163.183)$ & $-31 \%$ & $-152 \%$ \\
\hline 3 & PT. Berlian Laju Tanke & 55. & (12.127) & $(11.5$ & $-122 \%$ & $-5 \%$ \\
\hline 4 & PT. Batavia Prosperindo Trans Tbk & 14.431 & 8.108 & 3.116 & $-44 \%$ & $-62 \%$ \\
\hline 5 & PT. Samudera In & 75.704 & $(837$. & $(32.736)$ & $-1.206 \%$ & $-96 \%$ \\
\hline 6 & PT. Express Transindo Utama Tbk & $(836.820)$ & $(276.073)$ & $(53.222)$ & $-67 \%$ & $-81 \%$ \\
\hline 7 & PT. Temas Tbk & 34.819 & 100.615 & 52.214 & $189 \%$ & $-48 \%$ \\
\hline 8 & $\begin{array}{l}\text { PT. WEHA Transportasi Indonesia } \\
\text { Tbk }\end{array}$ & 3.191 & 4.519 & $(33.601)$ & $42 \%$ & 44 \\
\hline
\end{tabular}

Sumber: Data Diolah Tahun 2021 dari website: www.idx.co.id

Data di atas menunjukkan perusahaan transportasi pada tahun 2019-2020 mengalami penurunan laba dan kerugian, kecuali PT. Temas Tbk mengalami pertumbuhan laba di tahun 2019 sebesar 189\% dan PT. WEHA Transportasi Indonesia Tbk sebesar 42\%. Sedangkan, pada tahun 2020 semua perusahaan mengalami penurunan laba. Perusahaan yang mengalami penurunan laba paling tajam pada tahun 2019 adalah PT. Samudera Indonesia Tbk yaitu $-1.206 \%$ dan di tahun 2020 adalah PT. WEHA Transportasi Indonesia Tbk sebesar $-844 \%$. Kondisi ini membuat semua perusahaan berada dalam kesulitan keuangan, yakni kondisi dimana perusahaan mengalami kegagalan usaha.

Menurut Kwon dan Wild (1994) yang dikutip (Dwijayanti, 2010) bahwa financial distress secara signifikan terkait dengan informativeness laporan tahunan. Hasil penelitiannya menunjukkan bahwa pemegang saham bereaksi terhadap laporan tahunan tersebut secara signifikan yang bisa dilihat melalui harga saham dan reaksi tersebut lebih besar untuk dua tahun sebelum dan tahun pada saat terjadinya financial distress dibandingkan dengan periode sebelum terjadinya financial distress.

Penelitian mengenai financial distress telah dilakukan oleh Breaver (1966), kemudian dilanjutkan oleh Altman (1968), Springate (1978), (Zmijweski, 1984), dimana pada penelitian ini penulis memilih menggunakan model Altman untuk melakukan prediksi financial distress. Model tersebut dikenal dengan nama Z-Score. Sampel yang digunakan (Altman I Edwarrd, 1968) dalam penelitiannya berjumlah 66 perusahaan selama 20 tahun (1946-1965). Sampel tersebut terbagi dua kelompok, yaitu 33 perusahaan yang dianggap bangkrut dan 33 perusahaan lainnya tidak bangkrut. Altman menggunakan metode step-wise multivariate discriminant analysis (MDA) dalam penelitiannya. Seperti regresi logistik, teknik statistika ini juga biasa digunakan untuk membuat metode dimana variabel dependennya merupakan variabel kualitatif. Perusahaan yang digunakan Altman hanya berasal dari industri manufaktur. Hasil penelitiannya memiliki akurasi mencapai $95 \%$ jika menggunakan data 1 tahun sebelum kondisi financial distress. Persentase error-nya 6\% untuk Type I dan 3\% untuk Type II. Jika menggunakan data 2 tahun sebelum distress, akurasinya mencapai $83 \%$.

Di Indonesia juga telah dilakukan penelitian mengenai financial distress yakni (Prasetyo, Noor and Amiruddin, 2018) yang melakukan penelitian pada Perusahaan Transportasi 
Darat dan Terdaftar di BEI tahun 2012-2017 dengan metode Altman Z Score Modifikasi, hasil penelitiannya menyatakan bahwa PT Eka Sari Lorena Transport, Tbk berada pada kriteria grey area pada tahun 2012 dan tahun 2013, pada tahun 2014 - 2017 terjadi peningkatan score menjadi lebih dari 2,6 yang menjadikan perusahaan berada pada kriteria safe area, sedangkan PT Express Transindo Utama, Tbk berada pada kriteria grey area pada tahun 2012 - 2016, pada tahun 2017 terjadi penurunan score menjadi kurang dari 1,1 yang menjadikan perusahaan berada pada kriteria distress area. Meskipun di tahun 2017 PT Express Transindo Utama, Tbk berada pada area financial distress, tetapi laporan keuangan dan tahunan yang dipublikasi oleh Bursa Efek Indonesia bahwa PT Express Transindo Utama, Tbk tahun 2020 masih tercatat sahamnya di Bursa Efek Indonesia (www.idx.co.id).

Atas dasar masalah di atas maka rumusan masalah yang akan diteliti adalah bagaimana mengalisis financial distress pada Perusahaan Sub Sektor Transportasi di Bursa Efek Indonesia Tahun 2019-2020?

\section{Tinjauan Pustaka}

Financial distress adalah tahap penurunan kondisi keuangan yang terjadi sebelum kebangkrutan ataupun likuidasi (Platt and Platt, 2002). Sedangkan Financial distress menurut (Altman and Hotchkiss, 2006) yaitu:

a. Kegagalan ekonomi (Economic failure), adalah tingkat pengembalian modal yang lebih rendah dari modal yang diinvestasikan, termasuk pendapatan yang tidak mampu menutupi biaya operasionalnya namun perusahaan tidak menghentikan kegiatan operasinya. Perlu dicatat bahwa perusahaan mungkin gagal secara ekonomi selama bertahun-tahun, namun tidak pernah gagal memenuhi kewajibannya.

b. Kegagalan bisnis (Business failure), adalah perusahaan menghentikan kegiatan operasinya, disertai dengan eksekusi, penyitaan dan tidak memenuhi kewajibannya pada kreditor serta penyelesaiannya dilakukan di pengadilan.

c. Insolvency, terbagi dua macam, yaitu technical insolvency dan insolvency in bankruptcy.

1) Technical insolvency atau Kepailitan teknis ada ketika perusahaan tidak dapat memenuhi kewajibannya saat ini, menandakan kurangnya likuiditas.

2) Insolvency in bankcruptcy atau Kepailitan dalam arti kebangkrutan lebih serius dibandingkan dengan technical insolvency. Perusahaan dikatakan mengalami insolvency in bankruptcy jika nilai buku hutang melebihi nilai pasar aset. Oleh karena itu, kekayaan bersih perusahaan yang sebenarnya adalah negatif.

d. Gagal bayar (default) merupakan kondisi dimana debitur melanggar perjanjian dengan pihak kreditor dalam memenuhi kewajiban keuangan sehingga secara teknis dapat diambil tindakan hukum.

Penyebab terjadinya financial distress menurut Damodaran (1997) yang dikutip oleh

(Carolina, Marpaung and Pratama, 2018) menyatakan bahwa:

1. Besarnya jumlah hutang.

Kesalahan dalam pengambilan prakiraan hutang perusahaan sehingga perusahaan tidak dapat menutupi biaya yang timbul akibat operasi perusahaan akan menimbulkan kewajiban bagi perusahaan untuk mengembalikan hutang di masa mendatang. Ketika tagihan jatuh tempo, sedangkan perusahaan tidak mempunyai cukup dana untuk melunasi tagihan-tagihan yang ada, sehingga terjadi penyitaan harta.

2. Kerugian dalam kegiatan operasional perusahaan selama beberapa tahun 
Kerugian dalam aktivitas operasional yang menimbulkan arus kas negatif dalam perusahaan. Hal ini dikarenakan beban operasional lebih besar dari pendapatan yang diterima perusahaan.

3. Kesulitan arus kas

Keadaan dimana pendapatan perusahaan dari hasil kegiatan operasi tidak cukup untuk menutupi beban-beban usaha yang timbul atas aktivitas operasi perusahaan atau dapat terjadi karena adanya kesalahan manajemen ketika mengelola aliran kas perusahaan dalam melakukan pembayaran aktivitas perusahaan dimana dapat memperburuk kondisi keuangan perusahaan.

\section{Model Altman}

Analisis diskriminan Altman merupakan salah satu teknik statistik yang bisa digunakan untuk memprediksi adanya kebangkrutan suatu perusahaan (Altman I Edwarrd, 1968). Altman telah mengkombinasikan beberapa rasio menjadi model prediksi dengan teknik statistik. Persamaan dari model Altman yang pertama adalah sebagai berikut:

$$
Z=0,012 X 1+0,014 X 2+0,033 X 3+0,006 X 4+0,999 X 5
$$

Dimana : $X_{1}=$ Working capital/Total assets

$\mathrm{X}_{2}=$ Retained Earnings/Total assets

$\mathrm{X}_{3}=$ Earnings before interest and taxes/Total assets

$\mathrm{X}_{4}=$ Market value equity/Book value of total debt

$X_{5}=$ Sales $/$ Total assets

$\mathrm{Z}=$ Overall Index

Nilai $Z$ merupakan indeks keseluruhan fungsi multiple discriminant analysis, dengan kriteria sebagai berikut:

- Jika nilai $Z<1,8$ maka perusahaan mengalami bangkut (bankruptcy).

- Jika nilai $1,8<Z<2,99$ maka perusahaan berada pada zona abu-abu (grey area).

- Jika nilai $Z>2,99$ maka perusahaan tidak bangkut (nonbankruptcy).

\section{Model Altman Modifikasi ke-3}

Pada tahun 1995, Altman melakukan penelitian kembali mengenai potensi kebangkrutan perusahaan-perusahaan selain perusahaan manufaktur baik go public maupun tidak go public. Formula Z-Score terakhir merupakan rumus yang dinilai sangat fleksibel karena dapat digunakan untuk berbagai jenis bidang usaha perusahaan dan cocok digunakan di negara berkembang seperti Indonesia (Rudianto, 2013:257). Model ini dikenal dengan model Altman Modifikasi. Berikut rumus Z-Score model Altman III untuk berbagai jenis perusahaan (Rudianto, 2013): 


$$
\mathrm{Z}=6,56 \mathrm{X1}+3,26 \times 2+6,72 \times 3+1,05 \times 4
$$

$$
\text { Dimana: } \begin{aligned}
\mathrm{X}_{1} & =\text { Net Working Capital to Total Assets (WCTA) } \\
\mathrm{X}_{2} & =\text { Retained Earnings to Total Assets } \\
\mathrm{X}_{3} & =\text { Earning Before Interest and Taxes to Total } \\
\mathrm{X}_{4} & =\text { Market Value Equity to Book Value of Debt } \\
\mathrm{Z} & =\text { Overall Index }
\end{aligned}
$$

Hasil perhitungan dengan menggunakan rumus Z-Score tersebut akan menghasilkan skor yang berbeda antara satu perusahaan dengan perusahaan lainnya. Skor tersebut dibandingkan dengan standar penilaian ini untuk menilai keberlangsungan hidup perusahaan sebagai berikut :

- Jika nilai $Z<1,1$ termasuk zona berbahaya (bankruptcy).

- Jika nilai $1,1<Z<2,99$ maka perusahaan berada pada zona abu-abu (grey area).

- Jika nilai $Z>2,6$ maka perusahaan pada zona aman (nonbankruptcy).

Pada penelitian ini penulis menggunakan motode Altman modifikasi ke-3 untuk melakukan analisis data.

\section{Metodologi Penelitian}

Jenis penelitian yang dilakukan dalam penelitian ini adalah penelitian kualitatif. Objek penelitian pada perusahaan Transportasi yang terdaftar di Bursa Efek Indonesia dari Tahun 2019-2020. Populasi penelitian ini adalah perusahaan yang terdaftar di Bursa Efek Indonesia. Sampel yang digunakan dengan metode purposive sampling, sehingga terdapat 26 perusahaan yang memenuhi kriteria sebagai berikut:

\section{Tabel 2}

Sampel Sub Sektor Transportasi yang Terdaftar di Bursa Efek Indonesia Tahun 2019-2020

\begin{tabular}{clc}
\hline No & \multicolumn{1}{c}{ Keterangan } & Jumlah \\
\hline 1. & $\begin{array}{l}\text { Perusahaan yang bergerak pada sub sektor Transportasi yang terdaftar di } \\
\text { Bursa Efek Indonesia dari tahun 2019-2020 }\end{array}$ & 28 \\
2. & $\begin{array}{l}\text { Perusahaan yang tidak melakukan publikasi laporan keuangan di BEI } \\
\text { pada tahun 2019-2020. }\end{array}$ & $(2)$ \\
3. $\begin{array}{l}\text { Perusahaan menggunakan data laporan keuangan yang berakhir pada } \\
\text { bulan Desember yang telah diaudit. }\end{array}$ & 26 \\
\hline & \multicolumn{1}{c}{ Jumlah Sampel } & 26 \\
\hline
\end{tabular}

Sumber: www.idx.co.id

Data yang digunakan merupakan data sekunder, yaitu laporan keuangan dan telah dipublikasikan secara berturut-turut pada website bursa efek Indonesia melalui www.idx.co.id. Metode analisis data yang digunakan adalah analisis deskriptif. Metode deskriptif adalah untuk dapat menjelaskan rumusan masalah yang diteliti berkenaan dengan keberadaan variabel mandiri, variabel mandiri adalah variabel yang berdiri sendiri, bukan variabel independen (Sugiyono, 2011). 


\section{Analisis Data dan Pembahasan}

Berdasarkan perhitungan data dengan persamaan Altman Modifikasi ke-3 diperoleh hasil nilai Z Score pada Sub Sektor Transportasi di Bursa Efek Indonesia Tahun 2019-2020 sebagai berikut:

Tabel 3

Nilai Z Score Papan Utama Pencatatan Sektor Transportasi Tahun 2019-2020

\begin{tabular}{|c|c|c|c|c|c|c|c|c|}
\hline \multirow{2}{*}{ No } & \multirow{2}{*}{ Nama Perusahaan } & \multirow{2}{*}{ Tahun } & \multicolumn{5}{|c|}{ Z Score } & \multirow{2}{*}{ Zona } \\
\hline & & & $0,012 X_{1}$ & $0,014 X_{2}$ & $0,033 X_{3}$ & $0,006 X_{4} 2$ & Z SCORE & \\
\hline \multirow{2}{*}{1} & \multirow{2}{*}{$\begin{array}{l}\text { PT. Adi Sarana } \\
\text { Armada Tbk }\end{array}$} & 21 & $(0.795)$ & 0.321 & 0.501 & 0.400 & 0.427 & Berbahaya \\
\hline & & 2020 & $(1.027)$ & 0.359 & 0.419 & 0.405 & 0.156 & Berbahaya \\
\hline \multirow{2}{*}{2} & \multirow{2}{*}{ PT. Blue Bird Tbk } & 2019 & 0.164 & 1.1 & 0.448 & 2.816 & 4.546 & Aman \\
\hline & & 2020 & 0.544 & 1.068 & 0.064 & 2.725 & 4.400 & Aman \\
\hline \multirow{2}{*}{3} & \multirow{2}{*}{$\begin{array}{l}\text { PT. Berlian Laju } \\
\text { Tanker Tbk }\end{array}$} & 2019 & $(0.423)$ & $(60.406)$ & 0.168 & 0.876 & (59.785) & Berbahaya \\
\hline & & 2020 & $(0.620)$ & $(61.588)$ & 0.038 & 0.767 & (61.402) & Berbahaya \\
\hline \multirow[b]{2}{*}{4} & \multirow{2}{*}{$\begin{array}{l}\text { PT. Batavia } \\
\text { Prosperindo Trans } \\
\text { Tbk }\end{array}$} & 2019 & $(1.535)$ & 0.168 & 0.583 & 0.722 & $(0.062)$ & Berbahay \\
\hline & & 2020 & $(1.441)$ & 0.213 & 0.416 & 0.756 & (0.056) & Berbahaya \\
\hline \multirow{2}{*}{5} & \multirow{2}{*}{$\begin{array}{l}\text { PT. Samudera } \\
\text { Indonesia Tbk }\end{array}$} & 2019 & 0.599 & 0.832 & 0.149 & 0.958 & 2.539 & bu \\
\hline & & 2020 & 0.646 & 0.714 & 0.125 & 0.764 & 2.250 & Abu-abu \\
\hline \multirow[b]{2}{*}{6} & \multirow{2}{*}{$\begin{array}{l}\text { PT. Express } \\
\text { Transindo Utama } \\
\text { Tbk }\end{array}$} & 2019 & $(6.998)$ & $(9.463)$ & $(4.776)$ & $(0.511)$ & (21.748) & Berbahaya \\
\hline & & 2 & ) & (19.526) & 729) & $(0.715)$ & 8) & Berbahaya \\
\hline \multirow{2}{*}{7} & \multirow{2}{*}{ PT. Temas Tbk } & 2019 & $(0.930)$ & 0.964 & 0.616 & 0.596 & 1.246 & Abu-abu \\
\hline & & 2020 & $(0.842)$ & 0.857 & 0.413 & 0.484 & 0.911 & Berbahaya \\
\hline \multirow[b]{2}{*}{8} & \multirow{2}{*}{$\begin{array}{l}\text { PT. WEHA } \\
\text { Transportasi } \\
\text { Indonesia Tbk }\end{array}$} & 2019 & $(0.471)$ & 0.12 & 0.412 & 1.354 & 1.418 & Abu-al \\
\hline & & 2020 & $(0.578)$ & $(0.350)$ & $(0.532)$ & 1.204 & $(0.256)$ & Berbahaya \\
\hline & \multirow{2}{*}{$\begin{array}{l}\text { PT. Maming Enam } \\
\text { Sembilan Mineral } \\
\text { Tbk }\end{array}$} & 2019 & 1.129 & 0.307 & 0.637 & 0.699 & 2.772 & Aman \\
\hline & & 2020 & 1.103 & 0.212 & 0.369 & 0.583 & 2.267 & Abu-abu \\
\hline \multirow{2}{*}{10} & \multirow{2}{*}{$\begin{array}{l}\text { PT. AirAsia } \\
\text { Indonesia Tbk }\end{array}$} & 2019 & $(2.612)$ & $(7.896)$ & $(0.483)$ & 0.088 & (10.903) & Berbahaya \\
\hline & & 2020 & $(5.162)$ & $(4.961)$ & $(2.401)$ & $(0.340)$ & (12.863) & Berbahaya \\
\hline \multirow{2}{*}{11} & \multirow{2}{*}{$\begin{array}{l}\text { PT. Dewata } \\
\text { Freightinternational } \\
\text { Tbk }\end{array}$} & 2019 & 0.013 & 0.066 & 0.186 & 0.881 & 1.145 & Abu-abu \\
\hline & & 2020 & $(0.842)$ & 0.508 & 0.622 & 0.381 & 0.670 & Berbahaya \\
\hline \multirow{2}{*}{12} & \multirow{2}{*}{$\begin{array}{l}\text { PT. Jaya Trishindo } \\
\text { Tbk }\end{array}$} & 2019 & 1.165 & 0.718 & 1.429 & 1.944 & 5.256 & Aman \\
\hline & & 2020 & 0.267 & 0.477 & 0.318 & 0.681 & 1.743 & Abu-abu \\
\hline \multirow[b]{2}{*}{13} & PT. Indonesia & 2019 & (1.777) & (3.297) & $(0.250)$ & 1.486 & (3.837) & Berbahaya \\
\hline & $\begin{array}{l}\text { Transport \& } \\
\text { Infrastruktur Tbk }\end{array}$ & 2020 & $(2.567)$ & $(4.126)$ & $(0.477)$ & 0.404 & $(6.765)$ & Berbahaya \\
\hline 14 & & 2019 & $(0.261)$ & 0.033 & 0.426 & 2.369 & 2.566 & Abu-abu \\
\hline 14 & Berja & 2020 & 0.672 & 0.142 & 0.544 & 4.534 & 5.893 & Aman \\
\hline
\end{tabular}




\begin{tabular}{|c|c|c|c|c|c|c|c|c|}
\hline & \multirow{2}{*}{$\begin{array}{l}\text { PT. Krida Jaringan } \\
\text { Nusantara Tbk }\end{array}$} & 2019 & 0.397 & 0.126 & 0.056 & 33.559 & 34.137 & Aman \\
\hline & & 2020 & 0.490 & 0.043 & $(0.072)$ & 7.320 & 7.780 & Aman \\
\hline \multirow{2}{*}{16} & \multirow{2}{*}{$\begin{array}{l}\text { PT. Eka Sari Lorena } \\
\text { Transport Tbk }\end{array}$} & 2019 & 0.463 & $(0.667)$ & $(0.102)$ & 6.614 & 6.308 & Aman \\
\hline & & 2020 & $(0.118)$ & $(1.265)$ & $(0.921)$ & 4.375 & 2.072 & Abu-abu \\
\hline \multirow[b]{2}{*}{17} & \multirow{2}{*}{$\begin{array}{l}\text { PT. Mitra } \\
\text { International } \\
\text { Resources Tbk }\end{array}$} & 2019 & 0.554 & $(11.986)$ & 0.171 & 2.106 & $(9.155)$ & Berbahaya \\
\hline & & 2020 & 0.167 & $(13.475)$ & $(0.122)$ & 2.224 & (11.207) & Berbahaya \\
\hline \multirow{2}{*}{18} & \multirow{2}{*}{$\begin{array}{l}\text { PT. Pelayaran Nelly } \\
\text { Dwi Putri Tbk. }\end{array}$} & 2019 & 1.378 & 1.280 & 0.757 & 8.092 & 11.507 & Aman \\
\hline & & 2020 & 1.439 & 1.399 & 0.627 & 8.277 & 11.742 & Aman \\
\hline \multirow[b]{2}{*}{19} & \multirow{2}{*}{$\begin{array}{l}\text { PT. Prima } \\
\text { Globalindo Logistik } \\
\text { Tbk. }\end{array}$} & 2019 & $(0.164)$ & 0.656 & 0.619 & 1.691 & 2.803 & Aman \\
\hline & & 2020 & 1.339 & 1.056 & 0.667 & 2.055 & 5.118 & Aman \\
\hline \multirow[b]{2}{*}{20} & \multirow{2}{*}{$\begin{array}{l}\text { PT. Prima } \\
\text { Globalindo Logistik } \\
\text { Tbk }\end{array}$} & 19 & 0.772 & 92 & 0.354 & 4.713 & 0 & Aman \\
\hline & & 2020 & 0.818 & 0.094 & 0.204 & 10.199 & 11.314 & Aman \\
\hline \multirow{2}{*}{21} & \multirow{2}{*}{ PT. Steady Safe Tbk } & 2019 & $(3.038)$ & $(7.076)$ & 1.027 & 0.132 & (8.955) & Berbahaya \\
\hline & & 2020 & (3.390) & (8.030) & 0.497 & 0.185 & (10.739) & Berbahaya \\
\hline \multirow{2}{*}{22} & \multirow{2}{*}{$\begin{array}{l}\text { PT. Satria Antaran } \\
\text { Prima Tbk }\end{array}$} & 2019 & 3.812 & $(0.597)$ & 1.801 & 2.228 & 7.244 & Aman \\
\hline & & 2020 & 3.389 & 0.031 & 1.390 & 2.000 & 6.810 & Aman \\
\hline \multirow{2}{*}{23} & \multirow{2}{*}{$\begin{array}{l}\text { PT. Sidomulyo } \\
\text { Selaras Tbk }\end{array}$} & 2019 & $(1.411)$ & $(1.071)$ & $(1.007)$ & 0.323 & (3.166) & Berbahaya \\
\hline & & 2020 & $(3.643)$ & $(2.101)$ & $(1.589)$ & 0.048 & $(7.285)$ & Berbahaya \\
\hline \multirow{2}{*}{24} & \multirow{2}{*}{$\begin{array}{l}\text { PT. Trimuda } \\
\text { Nuansa Citra Tbk }\end{array}$} & 2019 & 5.607 & $(0.470)$ & 1.897 & 5.044 & 12.077 & Aman \\
\hline & & 2020 & 1.894 & $(0.652)$ & 2.038 & 5.154 & 8.434 & Aman \\
\hline \multirow{2}{*}{25} & \multirow{2}{*}{$\begin{array}{l}\text { PT. Transkon Jaya } \\
\text { Tbk }\end{array}$} & 2019 & $(1.840)$ & 0.290 & 1.195 & 0.398 & 0.043 & Berbahaya \\
\hline & & 2020 & $(0.961)$ & 0.467 & 0.935 & 0.900 & 1.342 & Abu-abu \\
\hline \multirow{2}{*}{26} & \multirow{2}{*}{$\begin{array}{l}\text { PT. Guna Timur } \\
\text { Raya Tbk }\end{array}$} & 2019 & 0.126 & 0.403 & 0.261 & 2.957 & 3.747 & Aman \\
\hline & & 2020 & $(0.430)$ & 0.104 & $(0.605)$ & 2.943 & 2.013 & Abu-abu \\
\hline
\end{tabular}

Sumber: Data Diolah tahun 2021

Tabel di atas menunjukkan bahwa pada tahun 2019 terdapat 10 perusahaan berada pada zona berbahaya, 5 perusahaan pada zona abu-abu, dan 10 perusahaan berada pada zona aman. Sedangkan, tahun 2020 terdapat 12 perusahaan berada pada zona berbahaya, 6 perusahaan pada zona abu-abu, dan 8 perusahaan berada pada zona aman. Peringkat rasio keuangan yang paling dominan memberikan angka terhadap perolehan $\mathrm{Z}$ Score adalah $\mathrm{X}_{4}$ yaitu rasio Ekuitas/Total aset, sedangkan paling rendah adalah $X_{1}$ yaitu rasio Modal kerja/Total aset. Perolehan Z Score yang paling buruk adalah PT. Berlian Laju Tanker Tbk, faktornya adalah rendahnya likuiditas dan akumulasi kerugian yang dialami oleh perusahaan. Kemudian disusul oleh perusahaan PT. Express Transindo Utama Tbk dimana seluruh variabel $\mathrm{X}_{1}-\mathrm{X}_{4}$ memiliki angka negatif, yang berarti bahwa buruknya kinerja perusahaan secara keseluruhan.

\section{Kesimpulan, Implikasi, Saran dan Keterbatasan}

Simpulan dari penelitian ini bahwa perusahaan Sub Sektor Transportasi di Bursa Efek Indonesia pada tahun 2019 terdapat 10 perusahaan berada pada zona berbahaya, 5 
perusahaan pada zona abu-abu, dan 10 perusahaan berada pada zona aman. Sedangkan, tahun 2020 terdapat 12 perusahaan berada pada zona berbahaya, 6 perusahaan pada zona abu-abu, dan 8 perusahaan berada pada zona aman. Implikasinya adalah perusahaan yang mampu mempertahankan perolehan laba setiap tahunnya menunjukkan zscore berada pada zona aman, sebaliknya perusahaan yang mengalami akumulasi kerugian menyababkan zscore pada zona berbahaya. Saran untuk peneliti selanjutnya untuk menggunakan penelitian kuantitatif agar prediksi kebangkrutan perusahaan dapat dilakukan. Keterbatasan pada penelitian ini yaitu penulis menggunakan jenis penelitian kualitatif, sehingga sulit untuk melakukan tingkat persentase prediksi kebangkrutan perusahaan.

\section{Daftar Pustaka}

Altman, E. I. and Hotchkiss, E. (2006) Corporate Financial Distress and Bankruptcy, Corporate Financial Distress and Bankruptcy. doi: 10.1002/9781118267806.

Altman I Edwarrd (1968) 'Financial Ratios, Discriminant Analysis And The Prediction Of Corpporate Bankruptcy', The Journal Of Finance, XXIII(4), pp. 589-609.

Carolina, V., Marpaung, E. I. and Pratama, D. (2018) 'Analisis Rasio Keuangan untuk Memprediksi Kondisi Financial Distress (Studi Empiris pada Perusahaan Manufaktur yang Terdaftar di Bursa Efek Indonesia Periode 2014-2015)', Jurnal Akuntansi Maranatha, 9(2), pp. 137-145. doi: 10.28932/jam.v9i2.481.

Dwijayanti, S. (2010) 'Penyebab, Dampak, Dan Pbediksi Dari Financial Distress Serta Solusi Untuk Mengatasi Financial Distress', Jurnal Akuntansi Kontemporer, 2(2), pp. 191-205.

Platt, H. D. and Platt, M. B. (2002) 'Predicting corporate financial distress: Reflections on choice-based sample bias', Journal of Economics and Finance, 26(2), pp. 184-199. doi: $10.1007 /$ bf02755985.

Prasetyo, L. F., Noor, R. and Amiruddin (2018) 'Analisis prediksi financial distress pada perusahaan transportasi darat dan terdaftar di BEI pelaporan 2012-2017', Jurnal Akuntansi Multi Dimensi (Jamdi), 1(1), pp. 47-53.

Zmijweski, M. E. (1984) 'Methodological Issues Related to the Estimation of Financial Distress Prediction Models', Journal of Accounting Research, 22, pp. 59-82.

Rudianto. 2013. Akuntansi Manajemen Informasi untuk Pengambilan Keputusan Strategis. Jakarta: Erlangga

Peraturan Pemerintah No. 21 Pasal 4 Tahun 2020 tentang PSBB dalam rangka penanganan Covid-19.

Springate, G. L. 1978. Predicting the possibility of failure in a Canadian firm. Unpublished MBA project, Simon Fraser University. 
Ade Elza Surachman

Vol. 6 No. 2

\section{Buana Akuntansi}

ISSN 2528-1119

E-ISSN 2580-5452

Sugiyono. 2011. Metode Penelitian Bisnis. Cetakan Ketujuh. Bandung: CV Alfabeta.

www.idx.co.id

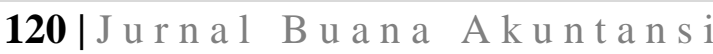

